\title{
Researchers recommend US AIDS vaccine trials
}

\begin{abstract}
Washington. A panel of scientists and AIDS activists agreed last week that several vaccines of uncertain efficacy against human immunodeficiency virus (HIV) should be tested in large human trials. The panel's decision, if acted upon, would settle a heated dispute about the fate of $\$ 20$ million that Congress has given to the US Army to test one vaccine produced by a US pharmaceutical company. Scientists and federal officials on the panel condemned the circumvention of peer review but agreed that the money should not be rejected.
\end{abstract}

The vaccine funding measure, a late amendment to this year's defence spending bill, orders the Army to spend the money on a "large-scale...clinical investigation of the GP-160 vaccine", referring to an HIV coat protein produced by MicroGeneSys Inc. of Meridian, Connecticut. The vaccine, which is intended to boost the immune system of people already infected with HIV, is being tested in several trials.

Many scientists have argued that the research community, not Congress, should decide which drugs deserve expensive largescale testing. They have also criticized MicroGeneSys's decision to employ Russell Long, a veteran former US senator from Louisiana, as a lobbyist. At the panel meeting, Bernadine Healy, director of the National Institutes of Health $(\mathrm{NIH})$, called the case an example of "law preempting science and scientific judgement" and said that "Congress has signed an uninformed consent form for patients with AIDS".

But the gp 160 measure also stipulates that the money will go to "other AIDS research needs of the Department of Defense" if the Secretary of Defense and the directors of NIH and the Food and Drug Administration (FDA) agree within six months after the legislation is enacted that the trial should not take place. Last week's panel was convened to advise Healy on whether the scientific data about gp 160 justifies large trials.

Scientists working with gp 160 explained at the meeting that it is too early to know whether the vaccine or any of its counterparts either prevents full-blown AIDS or prolongs lives. But panel members quickly agreed that because few good AIDS treatments exist - and because many people infected with HIV are too poor to receive good medical care - gp 160 and other promising therapeutic vaccines should be tested in massive trials.

Panel members also recommended that the trials collect other data about AIDS so that the money will not have been misspent if the vaccines perform poorly. The panel's final recommendation will be presented on 2 December at a meeting of the NIH director's advisory committee.

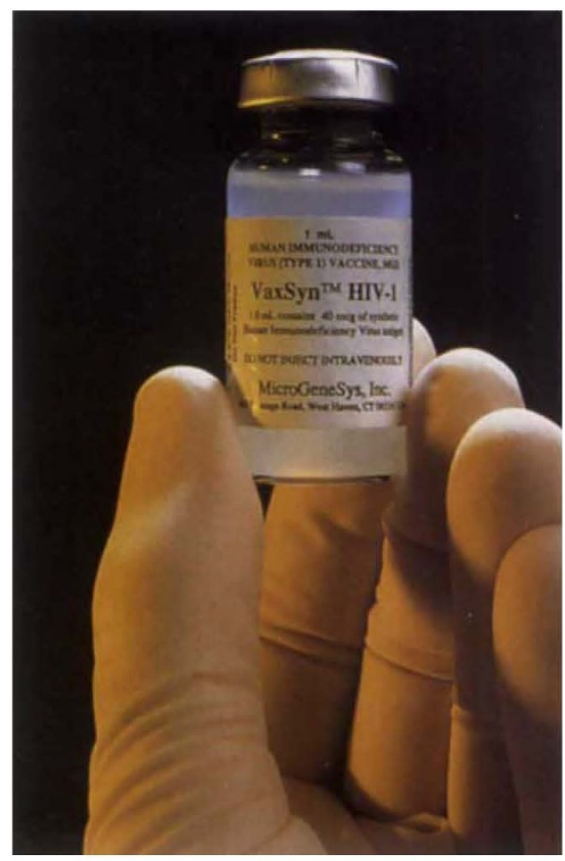

A vial of VaxSyn, a trial vaccine for HIV-1

The way in which the money was obtained was virtually ignored after Healy's opening speech, replaced with concern that $\$ 20$ million may not cover the cover of the planned trials. Nevertheless, it is hoped that the money will help to address both the epidemic and the demands of AIDS activists. "We hate the process, but we're focusing on what to do with the money", says Healy.

Traci Watson

\section{US proposes relaxing rules on trials of biotech crops}

San Francisco. Proposed rules that would loosen regulation of US field tests of genetically engineered crops have angered environmentalists and set industry executives worrying about a patchwork of state and federal policies. Both groups expect president-elect Bill Clinton to take a close look at the issue.

The proposal, published 6 November in the Federal Register, would allow US biotechnology companies to avoid a lengthy permit process and to begin certain field trials of corn, cotton, tomato, potato, soybean and tobacco with a simple notification to the US Department of Agriculture (USDA) on the same day they plant. Companies and researchers would decide whether their experiment satisfied USDA guidelines on allowable genetic constructs and their characteristics. The public has 60 days to comment.

Crops not on the list also could avoid the permit process if an institutional biosafety committee or state officials, reviewing data under the guidance of the USDA, decided that federal scrutiny was unnecessary. The final proposal omits transgenic plants grown to harvest pharmaceuticals but recommends cautious treatment for plants incorporating functionally intact genes from human or animal pathogens.

Industry and environmentalists formed a surprising coalition in support of an early version of the regulations (see Nature 359, $663 ; 1992$ ). But those rules were heavily revised after heated, last-minute negotiations between the agriculture department and the White House Council on Competitiveness, which has lobbied for greater deregulation in all parts of the economy.

Environmentalists say that the final revision amounts to industry self-regulation. "USDA had a germ of a good idea and the Council on Competitiveness perverted it into something that leaves little protection for the environment and the consumer", says Rebecca Goldburg, a biotechnology analyst for the Environmental Defense Fund who had supported the original proposal. The lack of advance notification will eliminate the opportunity for public comment and make it harder to prevent abuses, she adds.

Industry officials are concerned that the proposed regulations will open the door to stricter state regulations. "We need to have a sense of satisfaction both with the general public and with state regulators", says Richard Godown, president of the Industrial Biotechnology Association. "If we don't get that, there's going to be trouble for us." John Bedbrook, research director of DNA Plant Technology Inc. of New Jersey, praises the "liberalization" of the proposed regulations but says he hopes that the federal government will require companies to provide sufficient data on crops that they wish to be exempted.

Terry Medley, chief of USDA's biotechnology section, defended the revised proposals, saying that the agency was trying to make use of available expertise by shifting some of the regulatory responsibility to state and institutional bodies. "I don't think the substance of the proposal has changed."

Sally Lehrman 